\title{
Introduction: Changing Dickens
}

\author{
Joachim Frenk and Lena Steveker \\ Universität des Saarlandes
}

Cloisterham, the non-London setting of The Mystery of Edwin Drood that conjures up the Rochester Dickens knew as a child, is initially presented, in a somewhat timeless present tense, as immune to any kind of change: "A drowsy city, Cloisterham, whose inhabitants seem to suppose, with an inconsistency more strange than rare, that all its changes lie behind it, and that there are no more to come" (MED 23). Although the mindless bourgeoisie embodied by the new mayor, Mr. Sapsea, celebrate this changelessness, it seems to be one reason for Mr. Jasper's spiritual unrest and his need for an escape, which he satisfies in the Princess Puffer's opium den. Cloisterham's dreary initial changelessness changes completely in chapter 23 , which still must serve as the ending of the novel:

A brilliant morning shines on the old city. Its antiquities and ruins are surpassingly beautiful, with a lusty ivy gleaming in the sun, and the rich trees waving in the balmy air. Changes of glorious light from moving boughs, songs of birds, scents from gardens, woods, and fields - or rather, from the one great garden of the whole cultivated island in its yielding time-penetrate into the Cathedral, subdue its earthy odour, and preach the Resurrection and the Life. (MED 270)

At its conclusively provisional ending, Dickens's last novel offers one last change. Cloisterham changes from a city that is spiritually all but dead, its necropolis cathedral haunted by Durdles and Jasper, into a place joyously filled with the light of hope for the (capitalized) Resurrection and the Life. Dickens wrote the passage above in his 
Swiss Châlet at Gad's Hill, with a view of the Kentish countryside in the summer, very probably in the knowledge that he would have to die soon. Shortly afterward, John Forster encouraged every reader to see an analogy between Dickens's last finished chapter and his fading life: "the reader will observe with a painful interest, not alone its evidence of minute labour at this fast-closing hour of time with him, but the direction his thoughts had taken" (521). It was the direction of one last change for the better.

On 9 June 1870, having finished this chapter of Edwin Drood, Charles Dickens stopped changing, but the many readers of his works have made sure that he keeps being regarded as an agent of change. The images of Dickens himself, Michael Slater notes, only started changing more than sixty years after his death:

It was not until the mid-1930s, when revelations about his connection with Ellen Ternan began to surface, that [the prevailing] perception of Dickens [. . .] began to change, and a darker, more turbulent, and altogether more complex figure began emerging into the public consciousness. (623)

As this essay collection documents, it is a rewarding undertaking to discuss the numerous ways in which Charles Dickens was (and still is) an agent of change in an age of changes - of the plurality of Weltanschauungen, of the political system and the social cosmos, of technology, of the definitions, of the writing and the distribution of literature. And, we may add, of the changing notions of change itself.

In the twenty-first century, the notion of constant change has become the norm rather than the exception. Both in international companies and in other areas of the globalized, post- (or not-so-post)industrial societies, change has become ubiquitous, and change management is a familiar term in the economic discourse. Changes are sometimes highly welcome: in 2008, for instance, Barack Obama was elected president of the United States largely because he promised change, and most Europeans applauded his message of change, too. Although so many areas of life are restructured and changed for the most diverse reasonsand, occasionally, there seems to be no reason but change for its own sake-it is highly instructive to look at our immediate prehistory, the Victorian Age, to see how change was instigated, described, and managed then.

Charles Dickens's works, as agents and representations of all sorts of changes big and small, are excellent starting points for such an 
investigation. During his career as a writer and as a figure of public life, Dickens, who was initially irritated by isolated faults of the society surrounding him, became ever more dissatisfied with society as a whole. Consequently, the changes Dickens wanted to see changed; the longer and the more Dickens wrote, the more radical the changes he proposed became. Still, Dickens's ideas of change never condensed into an overarching system based on monumental abstractions. ${ }^{1}$ They primarily focused on the change of the individual, the famous change of heart toward kindness and generosity, often brought about by suffering and compassion - in contrast to, say, Karl Marx's ideas of necessary and, in his view, quasi-inevitable changes to come. For a time, Marx worked next to Dickens in the reading room of the British Library, but, as George Bernard Shaw commented in 1947, they were "living in the same city [. . .] yet they seem to us like creatures of a different species living in different worlds" (633). Dickens's idea of change was not Marx's, yet both saw the need to change the signs of their time, to minimize the collateral damages of technological capitalist modernity.

There are for instance the massive changes caused by the new railways, a new technology that physically, perceptually, and otherwise changed British society irreversibly within less than a century. Dickens is of course not the only contemporary to comment on the railway shock, but his prose is among the most powerful, for instance, when it describes a "hellish" railway construction site in Dombey and Son:

There were a hundred thousand shapes and substances of incompleteness, wildly mingled out of their places, upside down, burrowing in the earth, aspiring in the air, mouldering in the water, and unintelligible as any dream. Hot springs and fiery eruptions, the usual attendants upon earthquakes, lent their contributions of confusion to the scene. Boiling water hissed and heaved within dilapidated walls; whence, also, the glare and roar of flames came issuing forth; and mounds of ashes blocked up rights of way, and wholly changed the law and custom of the neighbourhood. (DS 79)

This passage spells out that the coming railway is "unintelligible as any dream," but at the same time, it seeks to render the change intelligible through its daring syntax and imagery-and ultimately through acknowledging how radical this change is, particularly in terms of the culture affected by the new technology.

Dombey and Son not only registers the enormous disruption of the cityscape caused by the railway; it also deals with the enormous 
acceleration of travel, perceived as a condensation of time and space, the changed attitudes toward the railway, the enormous array of railwayrelated products that commodified the new phenomenon and the terrible power of the new machines that must be controlled and in the end is let loose in the death of the villain Carker. When Mr. Dombey, mourning for his lost son, travels to Leamington by railway, the narrative voice takes over Dombey's analogy between the power of the railway and then turns it into a virtuoso piece of rhythmical and onomatopoetic exuberance that imitates the sound of the train journey itself:

\begin{abstract}
Away, with a shriek, and a roar, and a rattle, from the town, burrowing among the dwellings of men and making the streets hum, flashing out into the meadows for a moment, mining in through the damp earth, booming on in darkness and heavy air, bursting out again into the sunny day so bright and wide; away, with a shriek, and a roar, and a rattle, through the fields, through the woods, through the corn, through the hay, through the chalk, through the mould, through the clay, through the rock, among objects close at hand and almost in the grasp, ever flying from the traveller, and a deceitful distance ever moving slowly with him: like as in the track of the remorseless monster, Death! (DS 311)
\end{abstract}

The impression given here is that of a perceptive apparatus working at its limit to cope with the change of transport speed. Although the rhythm of the passage drives on mechanically and mercilessly, dissolving after a long syntactical period only to reaffirm itself triumphantly after the semicolon, the staccato impressions fired at the reader, forcing him or her to adapt to changes in a fleeting moment, indicate how much received ideas of time and space are threatened by a glance out of the window. "Away" - the traveler is always already gone, removed from any kind of fixed standpoint, dissolving like the surrounding land- or cityscape. The same goes for the deceptively close objects that keep changing their position from the moment they come into view. The shriek and the roar of the railway serve to animate it-elsewhere, locomotives are compared to "tame dragons" (DS 245) - and the verbs of the first syntactical period all signal the sheer physical power of the train to change the space it passes through: burrowing, flashing, booming, bursting. Toward the end of the paragraph, the rhythm starts to slow, similar to a train entering a station, and comes to a standstill in the last, mobility-denying word, an emphatic monosyllable whose final fricative mimics the locomotive's hissing when it has come to a standstill: death. 
Dickens's mastery of the English language spells out a perceptual change that, 130 years later, Wolfgang Schivelbusch defined as one of the central characteristics of railway travel in the nineteenth century:

[. . .] the idea that the railroad annihilated time and space must be seen as the reaction of perceptive powers that, formed by a certain transport technology, find suddenly that technology has been replaced by an entirely new one. [...] the railroad did not appear embedded in the space of the landscape the way coach and highway are, but seemed to strike its way through it. $(37)^{2}$

The new train station, "the heart of this great change" (DS 245), is a hub of restless Dickensian vitality and profusion, both admirable and uncanny. There is no single, stable view of the railway in Dickens's writing; instead, the new transportation technology and its implications are being constantly revisited and revised (see Philpotts; Mengel).

London, the prime space of Dickens's imagination, also changed at an unprecedented speed and to an unprecedented extent in the nineteenth century. Dickens, the "special correspondent for posterity," from the beginning of his writing career onwards traced London's many changes, as it were, obsessively. Although Dickens's narrators, in keeping with their creator's view of his own time and his regular derision of "the good old times," more often welcome change than they condemn it, there are also moments in which a sense of loss is evident. Here is one early example from Sketches by Boz, a description of the change of Scotland Yard first published in the Morning Chronicle on 4 October 1836:

Amidst all this change, and restlessness, and innovation, there remains but one old man, who seems to mourn the downfall of this ancient place. [...] A few years hence, and the antiquary of another generation looking into some mouldy record of the strife and passions that agitated the world in these times, may glance his eye over the pages we have just filled: and not all his knowledge of the history of the past, not all his black-letter lore, or his skill in book-collecting, not all the dry studies of a long life, or the dusty volumes that have cost him a fortune, may help him to the whereabouts, either of Scotland-yard, or of any one of the landmarks we have mentioned in describing it. (89-90)

What is lamented here is not the change of Scotland Yard per se, but the fact that it cannot be documented, while, ironically, the sketch sets 
out to do exactly that. At the same time, the pejorative way in which all kinds of written matter are described here-"mouldy record," "blackletter lore," dry studies of long life," "dusty volumes"-implicitly poses the question why it should be different with the newspaper, certainly even less connoted with a long shelf life than the coming antiquary's dusty volumes, in which this sketch first appeared. Dickens restlessly registers the changes around him, and his works, self-conscious, selfconfident, and full of appeals to their readers, strive to be accounts of change as much as agents of it.

In its eagerness to come to terms with the numerous transformations that were going on, the nineteenth century produced an entire discourse of change, which consisted of texts that differed widely in terms of quality and relevance. Dickens was sure enough aware of this discourse, and in his representations of change, he commented on it on a metalevel, as the following example illustrates. Of all Dickens's characters, the insufferable Mrs. Chick is given a little monologue on the topic of change:

"It's a world of change. Any one would surprise me very much, Lucretia, and would greatly alter my opinion of their understanding, if they attempted to contradict or evade what is so perfectly evident. Change!" exclaimed Mrs Chick, with severe philosophy. "Why, my gracious me, what is there that does not change! even the silkworm, who I am sure might be supposed not to trouble itself about such subjects, changes into all sorts of unexpected things continually." (DS 448-49)

In this passage, the rhetoric of change is a target of Dickens's satire. Mrs. Chick, perfectly incapable of anything approaching "severe philosophy," drones on in the most conventional platitudes about change to prepare Miss Tox for news of great changes in the small world of the two scheming ladies, of Mr. Dombey's second marriage, and of Miss Tox being disconnected from the House of Dombey altogether. The monumentally insignificant silkworm seems to have no direct connection to the relevant changes going on in the novel; it will never appear again. However, with a potentially telling analogy to the condition of the English working class, the silkworm produces a luxury material the Dombeys need for their conspicuous consumption. Yet it is, for Mrs. Chick, as unimportant as all non-Dombeys, such as, for instance, the unfortunate Miss Tox. Over and above Mrs. Chick's fishing for a convenient illustrative image of uncontrolled change, 
then, the silkworm serves as an ironic reminder that change is indeed ubiquitous and unstoppable, a process of life quite unimpressed by Mrs. Chick's opinions or by nineteenth-century change debates. Those who do not actively participate in the changes of their own time, like the ideologically petrified Mrs. Chick, will be forced to change. Dickens chose to participate in the changes of his time, to be an agent of change, and his ways of representing, advocating, criticizing, and instigating change are fascinating subjects of study. The essays assembled in this book address the multitudinous ways in which the notion of change has found entry into and is negotiated in Dickens's works.

The first section of this volume focuses on Dickens's strategies of promoting social change in and through his novels. Jerome Meckier argues that Pickwick Papers relies on a structural pattern of repetitions and reversals that at the same time represents the novel's privileged concept of effecting social change. Whereas Meckier's discussion of this early text shows Dickens as preferring reversal, the so-called change of heart, to revolution as the basic recipe for improving the condition humaine, Joel J. Brattin's essay focuses on Dickens's return to the idea of revolution in Bleak House. Brattin identifies and discusses three different kinds of revolution in this novel: violent struggle, the Industrial Revolution, and the gentle revolution of love, embodied by Esther Summerson in her social commitment and social responsibility. Bob Heaman adds one more dimension to our understanding of Dickens as an agent of social change. In his reading of Great Expectations, Heaman analyses Dickens's fundamentally artistic conception of social reform. In the essay that concludes this section, Bert Hornback also focuses on Dickens's concern with fiction as a means of reforming society. Touching on thirteen novels, Hornback explores the "power of doing good," which can be traced in both Dickens's novels and in his career as a writer.

The essays in the second section broaden the volume's critical perspective on Dickens's commitment to the public, taking into view what we would argue are changes of power-political and ideological-featuring in his writing. David Paroissien is concerned with analyzing the ambivalent and complex attitudes toward politics and progress expressed in Dickens's journalistic and fictional texts. In her reading of Martin Chuzzlewit, Nancy Metz explores how the novel's intersecting discourses of politics, history, and science reveal an interesting change in Dickens's beliefs about agency, authorship, 
and society following his American journey. Michael Hollington discusses Dickens's representation of capitalism in Dombey and Son. Analyzing this novel through the lens provided by Georg Simmel's Die Philosophie des Geldes (The Philosophy of Money), Hollington argues that Dickens criticizes nineteenth-century monetary culture for effecting a catastrophic change: estranging human beings from themselves.

Moving from Dickens as social critic to Dickens as writer of fiction, the third section of this volume looks at literary changes in Dickens's works. Malcolm Andrews's reading of The Pickwick Papers examines the comic techniques Dickens develops at the early stages of his career, adapting the original Pickwick remit to suit his own particular strengths as a humorist and adjusting inherited Regency styles of comedy to meet changing tastes on the eve of Victoria's succession. The following essay links satirical comedy to literary aesthetics as Matthias Bauer looks at acoustic changes in The Chimes (1844). His analysis of the text's dynamic sound patterns demonstrates how the story's eponymous chimes, and their reinterpreted rhythm, serve to represent the movements of life and human relationships. Turning from changes in Dickens's literature to Dickens as an agent of literary change, the essays by Norbert Lennartz and Herbert Foltinek focus on Dickens's relation to both his literary predecessors and successors. Whereas Lennartz detects elements of anti-Victorianism in Oliver Twist and David Copperfield that align Dickens with Romantic radicalism, Foltinek's discussion of Little Dorrit and Our Mutual Friend identifies these novels' characters as complex figures whose self-doubt, listlessness, and uncertainty anticipate the characters of modern literature.

The fourth section focuses on the changes that Dickens and his works evoked in popular culture and the theater. Dickens was both involved in and fascinated with nineteenth-century popular culture. Not only did he write for a large and diverse readership, producing literary commodities for mass consumption; popular culture also features strongly in his novels, as Doris Feldmann and Chris Pittard argue in their essays. Focusing on popular entertainments in Hard Times, Feldmann investigates Dickens's conception of popular culture as a vehicle for a "kinder understanding" across different social strata that forms part of a radical agenda subverting Victorian cultural hierarchies. Pittard traces the resonances of conjuring as a form of nineteenth-century popular entertainment in The Old Curiosity Shop. Reading the novel as a narrative of secular magic, he situates it within 
the mid-nineteenth-century debate about property and copyright. In his essay on Victorian dramatic adaptations of Bleak House, Chris Louttit focuses on yet another form of popular culture, the mid-Victorian East End theater scene. Louttit's reading of hitherto marginalized plays not only offers insight into the tastes and interests of Dickens's mass audience, but also presents Dickens as an agent of radical change in this arena as well as a great popular entertainer. The essay by Robert Tracy, which concludes this section, takes us to twenty-first-century drama. Focusing on Sebastian Barry's play Andersen's English (2010), Tracy sheds light on the theater's continuing engagement with Dickens. Thus Barry's play, which Tracy reads as a commentary on Dickens's selfimage as a man in charge of his fictional plots and of his life, indicates the ongoing changes in perception to which Dickens is still subjected today. Just as Andersen failed to read the dynamics of the Dickens household properly in 1857, we are always in danger of constructing a Dickens that suits our twenty-first-century tastes.

In his afterword, Edgar Rosenberg provides a Dickens retrospect of a more personal kind. Recalling his own first encounter with Dickens's texts as a teenage boy, Rosenberg's autobiographical essay portrays Dickens as a writer who not only fuelled his love for literature, but also taught a young Jewish refugee from Nazi Germany a new language to live in, and thus a new way of life. More than seventy years after his death, Dickens thus acted as the agent of a momentous change he cannot even have remotely foreseen.

\section{NOTES}

1 In his (unsigned) Household Words article "On Strike" (February 11, 1854), Dickens, who is close to the narrator persona in this short piece, is confronted with the question, "'Pray, what would you have, sir, [. . .] in the relations between Capital and Labor, but Political Economy?"' The narrator's comment is telling: "I always avoid the stereotyped terms in these discussions as much as I can, for I have observed, in my little way, that they often supply the place of sense and moderation" (qtd. in Flint 61).

2 On the same page, Schivelbusch gives a quotation from Heinrich Heine's Lutezia, (1843) which, although rhythmically less complex than Dickens's passage quoted here, gives vent to the same impression from an observing point of view. 


\section{BIBLIOGRAPHY}

Dickens, Charles. Dombey and Son. Ed. Andrew Sanders. London, 2002.

- - - . Great Expectations. Ed. Edgar Rosenberg. New York, 1999.

_ - _. Sketches by Boz. Ed. Dennis Walder. Harmondsworth, 1995.

- - - . The Mystery of Edwin Drood. Ed. David Paroissien. London, 2002.

Flint, Kate, ed. The Victorian Novelist: Social Problems and Social Change. London, 1987.

Forster, John. The Life of Charles Dickens. New York, 1908.

Mengel, Ewald, ed. The Railway Through Dickens's World: Texts from Household Words and All the Year Round. Frankfurt a. M., 1989.

Philpotts, Trey. "Dickens and Technology." A Companion to Charles Dickens. Ed. David Paroissien. London, 2011. 199-215.

Schivelbusch, Wolfgang. The Railway Journey: The Industrialization of Time and Space in the 19th Century. 1986. Berkeley, 1977.

Shaw, George Bernard. "Introduction to Great Expectations." Great Expectations. By Charles Dickens. London, 1947. v-xx. Rpt. in Dickens, Great Expectations. Ed. Edgar Rosenberg. New York, 1999. 631-41.

Slater, Michael. Charles Dickens. New Haven, 2009. 